\title{
Studies on infectious bursal disease maternal immunity decay curve in native and Lohmann chicken breeds
}

\author{
M. F. El-Kady ${ }^{1}$, A. M. Dahshan ${ }^{1}$, H. M. Madbouly. ${ }^{2}$ \\ ${ }^{1}$ Poultry Diseases Department, ${ }^{2}$ Virology Department, Faculty of Veterinary Medicine Beni-Suef \\ University Beni-Suef 62511, Egypt.
}

\begin{abstract}
This study was done to evaluate and study the decaying curve of IBD MDAbs of the native chicken breeds including (Fayoumi, Dandrawi, Senawi and Baladi) were taken in consideration as compared with (Lohmann white) layer type breed. The results showed that the decline of maternal immunity of IBDV in Lohmann is the faster followed by Senawi, Baladi, Fayoumi and Dandrawi and the 1 day IBD ELISA titers were shown to be nearly equal in Senawi $(5449 \pm 371)$ and Lohmann (4536 \pm 437$)$ and titer of Baladi chicks was close to the for mentioned two breeds $(5327 \pm 371)$, the Dandrawi $(4649 \pm 331)$ and Fayoumi $(4596 \pm 857)$ are lower but close to each other.

The standard deviation (SD) values recorded in Fayoumi breed showed great variation in the recorded titers, while of the other 4 groups seamed to be homogenous. Comparing the 22 day decline manner in titer it was clear that the loss in titer in Fayoumi (3494) and Lohmann (3413) was nearly equal and followed by Dandrawi (3093) and Baladi (2972) those showing lower titers. The recorded unprotected titer $\leq 400$ was detected at 43 days in Lohmann, Baladi and Senawi, 37 days in Dandrawi and 31 in Fayoumi. Percentage of decline from its original values showed that Fayoumi last $(75.95 \%)$ at 22 days followed by $(66.53 \%)$ in Dandrawi followed by $(62.78 \%)$ Lohmann,(55.79) Baladi and (55.19) Senawi. Different breeds showed different slope values that indicate differences in the decay of maternal antibodies. The predication of antibody titer for each breed as the slope in decline curve in Lohmann chicks showed highest values followed by Dandrawi chicks while the Fayoumi and Baladi were as the same values and on the other hand the Senawi showed the lowest value.
\end{abstract}

Infectious bursal disease (IBD) is a highly contiguous viral disease of young chickens. It is characterized by severe destruction of lymphoid cells, especially actively dividing Bcells of bursa of Fabricius, and the other organs of the immune system but with lesser degree (Cheville, 1977).In Egypt the disease was first recorded in commercial broiler chickens on the basis of histopathological examination (El Sergany et al., 1974). The first isolation and identification of IBDV was performed by (Ayoub and Malek, 1976).The outbreaks of IBD were reported by (Bastami 1980; Mousa et al., 1983; Amer et al., 1984 and 1986; El Batrawi and El Kady1990). Passively acquired antibodies have been shown to protect chickens from IBDV (Corley et al., 2002; Fahey et al.. 1987). The titers of antibodies in the circulation correlate with the efficacy of vaccination and the immune status of the flocks (Wyeth et al., 1981a, b). The frequency and the magnitude of positive results can be used to predict timing of vaccine application without interference with the chick's response to active immunization, and to assess the susceptibility of the flock to disease (van den Berg and Meulemans, 1991; Kouwenhoven and van den Bos, 1994). It was reported that the half life time of maternal antibodies to IBD averaged 3.5 days in broiler and 6-7 days (Fahey et al., 1991). Therefore, this Study was carried out to detect the possible difference in decay of IBD MDAb in 4 native breeds as compared with one foreign.

\section{Materials and methods}

Experimental chicks. A total number of 300 chicks were used during this study including 4 native breeds (Fayoumi, Dandrawi, Sinawi, and Baladi) were obtained from (Al-Azab project for poultry production, Fayoum) and one foreign breed (Loghman white) obtained from (Al-Wadi commercial company for poultry production). Dam hens of native breeds were aged 22 weeks and received oil IBD vaccine at 14 and 18 weeks of age; while the foreign breed was aged 26 weeks and vaccinated at 23 and 33 weeks.From each breed 60 one-day old chicks were used 
for studying decaying of maternal antibody. These chicks were floor reared under natural day light.

IBD ELISA Kits. IBDV-ELISA Kits were obtained from Kikegaard and Perry laboratories (Kpl), USA

Serum samples. Blood samples were collected in clean dry, sterile wesserman tubes. The tubes containing blood samples were stroppered and left in horizontal position for an hour at room temperature and then left for another hour at $4^{\circ} \mathrm{C}$ then centrifuged at 3000 r.p.m. for 15 minutes. Serum samples were carefully separated in a small Eppendorf vials, laboled and kept at $-20^{\circ} \mathrm{C}$ till used.

ELISA test procedures. ELISA test was carried out according to manufactural instructions.Titer- Relates $\mathrm{S} / \mathrm{P}$ at a 1:500 dilution to an endpoint titer: $\log 10$ titer $=1.09(\log 10 \mathrm{~S} / \mathrm{P})$

Statistical analysis. Statistical Analysis of variance (ANOVA) test was used to estimate differences among treatments according to (Steel and Torrie 1960). Correlation and linear regression analysis were also performed using Microsoft excel program.

Experiment. Four native breeds (Fayoumi, Dandrawi, Sinawi, and Baladi) and one foreign breed (Lohmann) were compared for the possible variation in IBDV maternal antibodies decay, antibody titers as measured by ELISA test. From each 60 day old chicks were obtained and possessing maternal antibodies against IBDV were used for each breed .Chicks were reared in an isolated rooms under strict hygienic measures. and fed commercial balanced broiler breeder ration and water ad libtum .Blood samples were collected randomly from 10 Chicks at 3 days interval from 1 day old chicks till 43 days of age. Collected blood samples centrifuged at 3000 r.p.m for 5 minutes. Sera were preserved at -20 0C until serologically tested. Mean titers for each age group and each breed were calculated (1) and Fig (1, 2). and statistically analyzed. The obtained results were shown in table (2) and Fig (3).

\section{Results}

Fayoumi. The detected MDAbs IBD antibodies as measured by ELISA test from 1 day to 3 days of life in Fayoumi chicks hatched from parent oil adjuvant parent birds showing the following :Mean ELISA titers at 1 day was $(4596 \pm 857)$ decreased sharply to $(2439 \pm 1329)$ at $10^{\text {th }}$ day and reach $(890 \pm 123)$ at 25 days of age. The decrease of antibody titers from 25 days of age $(890 \pm 123)$ gradually decreased to reach $(254 \pm 113) 43^{\text {rd }}$ day $f$ life. The half life titer of 1 day titer $(4596 \pm 857)$ kenotic to be about (2298) at 8 days, from (2298) to (1149) to $(574.5)$ in the $29^{\text {th }}$ day and reach unprotective titer ( $333 \pm 94)$ at 31 days of age .

Dandrawi. Results of MDAbs of Dandrawi chicks detected at the $1^{\text {st }}$ day was $(4649 \pm 331)$ and gradually decreased to reach $(2087 \pm 306)$ at the $19^{\text {th }}$ day followed by slow decrease to reach $(259 \pm 151)$ at $43^{\text {rd }}$ day. The half life time of day old titers $(4646 \pm 331)$ to $(2324.5)$ at 17 day to (1162.25) at 26 day to (581.12)at 33 day.The unprotective titer (376 \pm 198$)$ at 37 days of life.

Senawi. In Senawi chicks ELISA titers of 1 days was $(5449 \pm 371)$ decreased to $(2677 \pm 264)$ at the $19^{\text {th }}$ day and $(445 \pm 170)$ at $43^{\text {rd }}$ day of life. The half life time original 1 day titer $(5449 \pm 371)$ to reach $(2724.5)$ at about 18 day to (1362.25) at about 36 day of life and (681.25) at 40day.The unprotective titer $(354 \pm 107)$ at $43^{\text {rd }}$ day of life.

Baladi. Results of MDAbs in Baladi chicks detected at the $1^{\text {st }}$ day $\operatorname{was}(5327 \pm 356)$ and gradually decreased to reach $(2697 \pm 221)$ at the $19^{\text {th }}$ day followed by slow decrease to reach $(354 \pm 107)$ at $43^{\text {rd }}$ day. The half life time of day old titers $(5327 \pm 356)$ to $(2663.5)$ at 18 day to (1331.75) at 30 day to (665.87) at 39 day. The unprotective titer (354 \pm 198$)$ at 43days of life.

Lohmann. Results of MDAbs in Lohmann chicks that detected at the $1^{\text {st }}$ day as $(5436 \pm 437)$ and gradually decreased to reach $(2340 \pm 241)$ at the $19^{\text {th }}$ day followed by slow decrease to reach $(351 \pm 110)$ at $43^{\text {rd }}$ day. The half life time of day old titers $(5436 \pm 437)$ to (2718) at 18 day to (1359) at 29 day to (679.5) at 36 day. The unprotective titer $(351 \pm 110)$ at 37 days of life.

From the pervious obtained results the unprotective titer ocurre at titer $(\geq 400)$, while these breeds reached the unprotected titer at 31day for Fayoumi, 37 day in Dandrawi , 43 day in Senawi , 43 day in Baladi while in Lohmann at 37 day. The detected 1 day IBD ELISA titers were shown to be nearly equal in Senawi (5449 \pm 371) and Lohmann $(4536 \pm 437)$ and titer of Baladi chicks was close to the for mentioned two breeds $(5327 \pm 371)$.The Dandrawi $(4649 \pm 331)$ and Fayoumi (4596 \pm 857 ) are lower but close to each other Results showed in Table (1) Fig $(1,2)$. The SD values recorded in Fayoumi breed showing great variation in the recorded 


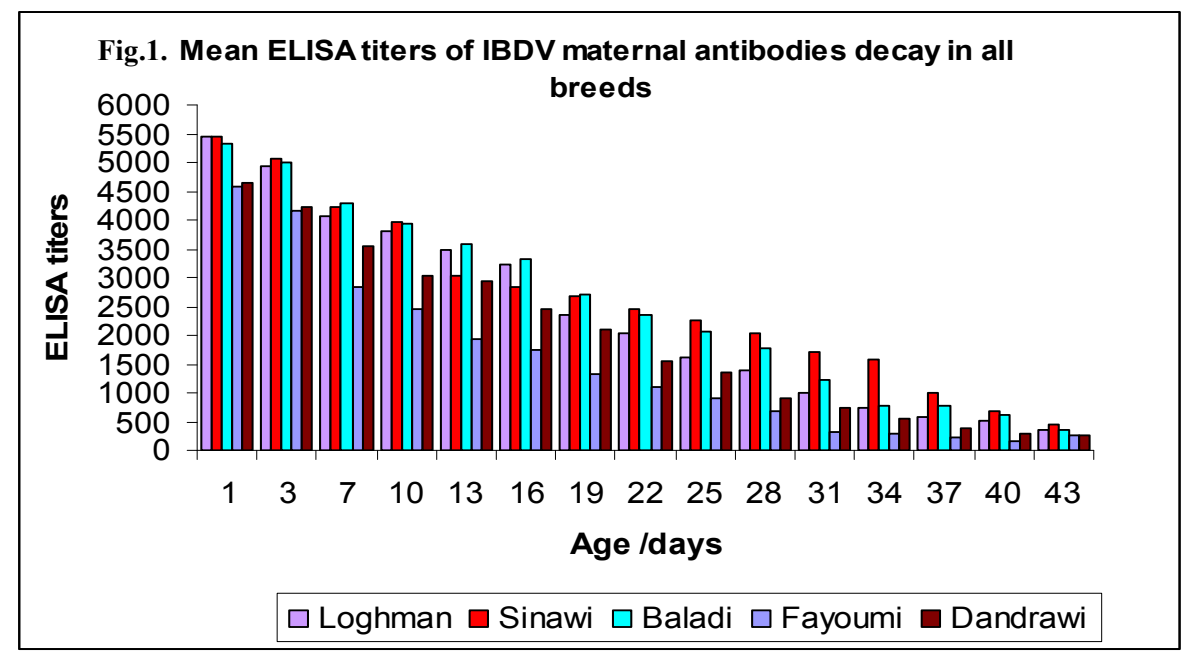

Table (1):Mean ELISA titers of IBDV maternal antibody decay in all breeds.

\begin{tabular}{cccccc}
\hline \multirow{2}{*}{ Age /days } & \multicolumn{5}{c}{ Mean ELISA titers of IBDV maternal antibodies decay } \\
\cline { 2 - 6 } & Fayoumi & Dandrawi & Sinawi & Baladi & Lohmann \\
\hline $\mathbf{1}$ & $4596 \pm 857$ & $4649 \pm 331$ & $5449 \pm 371$ & $5327 \pm 356$ & $5436 \pm 437$ \\
$\mathbf{3}$ & $4177 \pm 911$ & $4212 \pm 331$ & $5076 \pm 260$ & $4994 \pm 377$ & $4922 \pm 376$ \\
$\mathbf{7}$ & $2853 \pm 778$ & $3544 \pm 272$ & $4216 \pm 385$ & $4289 \pm 305$ & $4067 \pm 333$ \\
$\mathbf{1 0}$ & $2439 \pm 1329$ & $3025 \pm 321$ & $3965 \pm 388$ & $3947 \pm 265$ & $3791 \pm 272$ \\
$\mathbf{1 3}$ & $1932 \pm 595$ & $2931 \pm 191$ & $3030 \pm 250$ & $3593 \pm 309$ & $3492 \pm 332$ \\
$\mathbf{1 6}$ & $1741 \pm 345$ & $2463 \pm 252$ & $2830 \pm 311$ & $3317 \pm 217$ & $3221 \pm 293$ \\
$\mathbf{1 9}$ & $1333 \pm 269$ & $2087 \pm 306$ & $2677 \pm 264$ & $2697 \pm 221$ & $2340 \pm 241$ \\
$\mathbf{2 2}$ & $1105 \pm 188$ & $1556 \pm 340$ & $2444 \pm 339$ & $2355 \pm 233$ & $2023 \pm 238$ \\
$\mathbf{2 5}$ & $890 \pm 118$ & $1365 \pm 322$ & $2267 \pm 256$ & $2077 \pm 104$ & $1604 \pm 143$ \\
$\mathbf{2 8}$ & $663 \pm 123$ & $904 \pm 298$ & $2034 \pm 244$ & $1771 \pm 185$ & $1380 \pm 220$ \\
$\mathbf{3 1}$ & $333 \pm 94$ & $758 \pm 189$ & $1698 \pm 256$ & $1230 \pm 161$ & $988 \pm 173$ \\
$\mathbf{3 4}$ & $290 \pm 112$ & $533 \pm 125$ & $1579 \pm 371$ & $790 \pm 109$ & $726 \pm 165$ \\
$\mathbf{3 7}$ & $237 \pm 159$ & $376 \pm 198$ & $998 \pm 161$ & $775 \pm 156$ & $577 \pm 118$ \\
$\mathbf{4 0}$ & $152 \pm 101$ & $301 \pm 125$ & $666 \pm 163$ & $623 \pm 81$ & $511 \pm 143$ \\
$\mathbf{4 3}$ & $254 \pm 113$ & $259 \pm 151$ & $445 \pm 170$ & $354 \pm 107$ & $351 \pm 110$ \\
\hline
\end{tabular}

Table (2) Variation in the decay of maternal antibodies between native and foreign breeds.

\begin{tabular}{cllll}
\hline Breeds & R2 & r & Slope & Linear equation(y) \\
\hline Fayoumi & 0.8875 & 0.942 & 100.19 & $-100.19 \mathrm{x}+3714.3$ \\
Dandrawi & 0.9610 & 0.980 & 106.91 & $-106.91 \mathrm{x}+4275.8$ \\
Sinawi & 0.9640 & 0.981 & 110.21 & $-110.21 \mathrm{x}+5042.3$ \\
Baladi & 0.9863 & 0.993 & 120.68 & $-120.68 \mathrm{x}+5189.4$ \\
Lohmann & 0.9659 & 0.982 & 122.67 & $-122.67 \mathrm{x}+5053.2$ \\
\hline
\end{tabular}

$\mathrm{R} 2$ = correlation coefficient $\mathrm{Y}=$ simple linear regression equation. Slope $=\mathrm{A}$ regression slope of 1 means no differences measured in the dependent and independent items 

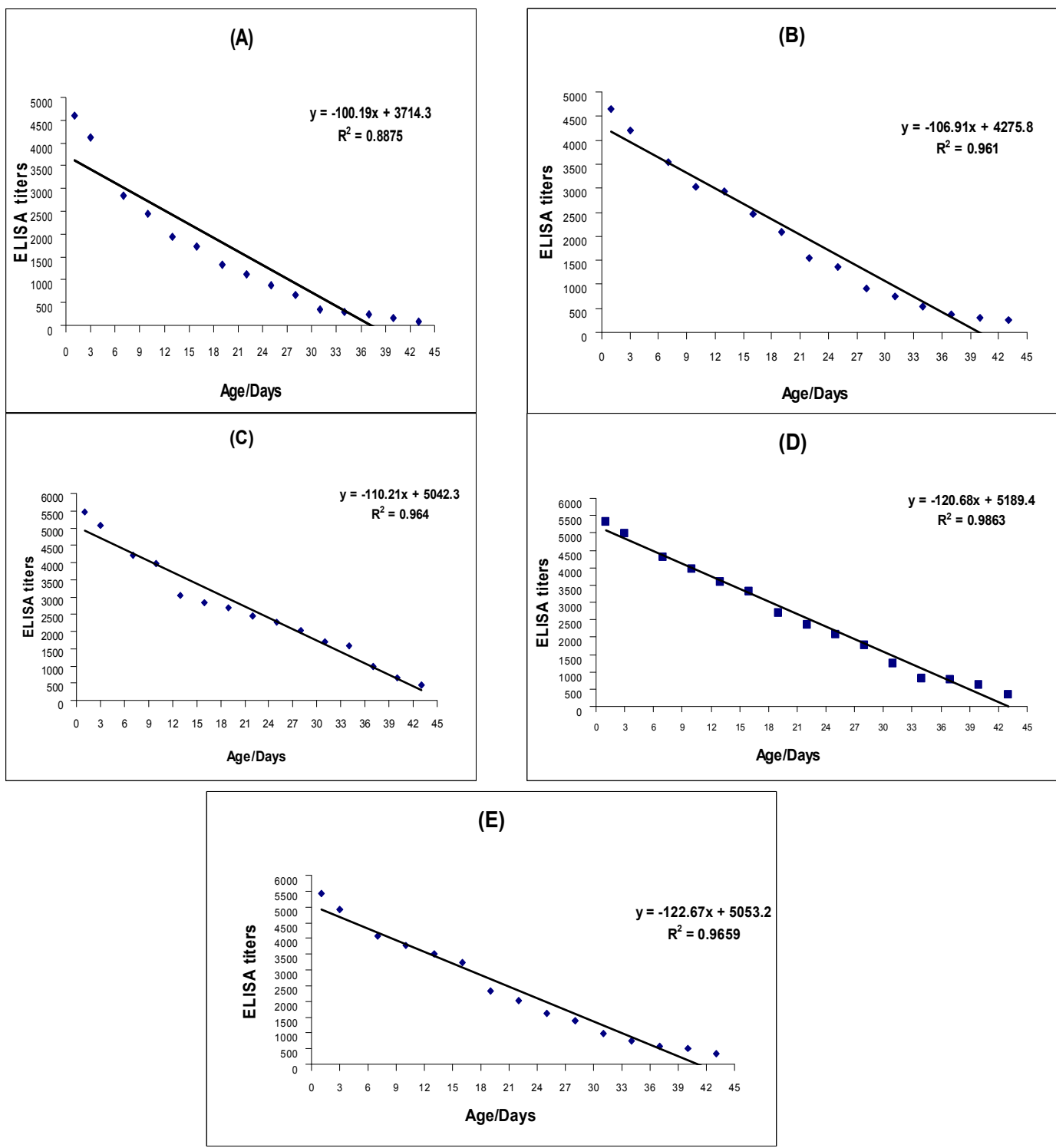

Fig. 2. A-Fayoumi breed /B- Dandrawi breed /C-Senawi breed /D-Baladi breed / E-Lohmann breed $\mathbf{R}=$ correlation coefficient, and $\mathbf{Y}=$ simple linear regression equation

Fig.3 . Variation in the decay of maternal antibodies between native and foreign breeds

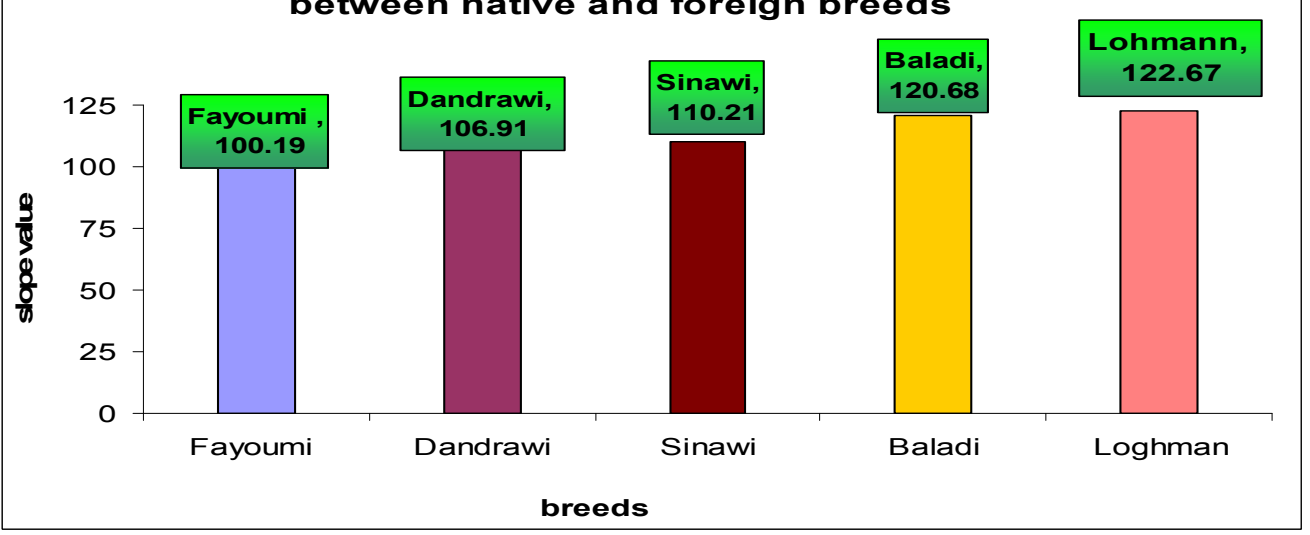


titers, while that of the other 4 groups seamed to be homogenous. Comparing the 22 day decline manner in titer it was clear that the loss in titer in Fayoumi (3494) and Lohmann (3413) are nearly equal and followed by Dandrawi (3093) and Baladi (2972) those showing lower titers. The recorded titer $\leq 400$ was detected at 43 days in Lohmann, Baladi and Senawi, 37 days in Dandrawi and 31 in Fayoumi. Percentage of decline from its original values showed that Fayoumi last $(75.95 \%)$ at 22 days followed by $(66.53 \%)$ in Dandrawi followed by $(62.78 \%)$ Lohmann, (55.79) Baladi and (55.19) Senawi. Results showed in Table (2) Fig (3). Prediction equation was calculated for each breed that allows the forecast of antibody titer decay. High correlation was observed between dependant and independent parameters of the regression analysis. Different breeds showed different slope values that indicate differences in the decay of maternal antibodies and the predication of antibody titer for each breed as the slope in decline curve in Lohmann chicks showed highest values followed by Baladi chicks while Senawi the and Dandrawi were as the same values and on the other hand the Fayoumi showed the lowest value.

\section{Discussion}

The vaccination of breeder and their chicks had been intended especially for IBD which discovered for the $1^{\text {st }}$ time by (Cosegrove 1962), hygienic measures still ineffective to prevent the disease (Benton et al., 1967).so vaccination is the most effective measures to control it. In this time importance of maternal immunity (MDAbs) was appeared to have a great role in protection of young chicks against early both infection and immunosuppression, it may interfere with vaccination procedures (Edison, 1980; Giambrone and Clay, 1986; Solano et al., 1986; Mazariegos et al., 1990; Wyeth and Chettle 1990; Van Den Berg and Muelemans 1991; Wyeth et al., 1992; Goddard et al., 1994; Chettle and Wyeth 1994). Since the appearance of variant vIBDV (Van Den Berg and Muelemans 1991) and very virulent strains of vvIBD, it became a problem of great importance(Van Den Berg 2000) as well as antigenic variation between field isolates and used vaccines ( Giambrone and Closser, 1990).The differences of maternal antibody decay of IBDV with regard to breed variation were evaluated. The relative susceptibilities of local Egyptian breeds to vvIBDV, a pathogen causing an economically important disease, were compared (Hassan et al.,
2002). This area attracted our attention to study decaying curve of IBD MDAbs in our native chicken breeds as well as their susceptibility to IBD infection in relation to their maternal immunity. The native chicken breeds including Fayoumi, Dandrawi, Senawi and Baladi were taken in consideration as compared with Lohmann white layer. ELISA test was adapted to estimate IBD antibodies in chick's sera at 1 day of age and every 3 days intervals till 43 days of age. Fayoumi chicks, mean ELISA titers at 1 day was (4596 \pm 857$)$ decreased sharply to $(2439 \pm 1329)$ at $10^{\text {th }}$ day and reach $(890 \pm 123)$ at 25 days of age. The decrease of antibody titers from 25 days of age $(890 \pm 123)$ gradually decreased to reach $(254 \pm 113) 43^{\text {rd }}$ day of life. These results agreed with those of (Marquardt $e t$ al., 1979) who concluded that ELISA test can be used to measure and detect IBD antibodies and of value for assessing that the decline of antibody titer was one log every 7-7.5 days during the $1^{\text {st }} 3$ weeks and then the depletion rate increased to be one $\log$ every 4 days. The maternal antibodies of Dandrawi chicks detected at the $1^{\text {st }}$ day as $(4649 \pm 331)$ and gradually decreased to reach $(2087 \pm 306)$ at the $19^{\text {th }}$ day followed by slow decrease to reach $(259 \pm 151)$ at $43^{\text {rd }}$ day. In Senawi chicks ELISA titers of 1 days was $(5449 \pm 371)$ decreased to $(2677 \pm 264)$ at the $19^{\text {th }}$ day and $(445 \pm 170)$ at $43^{\text {rd }}$ day of life. The maternal antibodies of Baladi chicks that detected at the $1^{\text {st }}$ day as $(5327 \pm 356)$ and gradually decreased to reach $(2697 \pm 221)$ at the $19^{\text {th }}$ day followed by slow decrease to reach $(354 \pm 107)$ at $43^{\text {rd }}$ day. The maternal antibodies of Lohmann chicks detected at the $1^{\text {st }}$ day as $(5436 \pm 437)$ and gradually decreased to reach $(2340 \pm 241)$ at the $19^{\text {th }}$ day followed by slow decrease to reach $(351 \pm 110)$ at $43^{\text {rd }}$ day. Results of this experiment clearly indicated that the half life time in Fayoumi about 8 days, Dandrawi 17, Senawi 18, Baladi 18 and Lohmann 18.and these results disagreed with the results of (Fahey et al., 1991) found the half live period of maternal immunity to be 6-7 days in layer pullets this period was shorter in broilers. It seemed that there was a relation ship between weights and half life time, this experiment was done to be a guide of the rate of declining of maternal antibodies in this type of chicks for the following experiments. This point can be in reverse with the growth rate of these breeds as Lohmann is the faster followed by Senawi, Baladi, Fayoumi and Dandrawi Results in (Table1) and (Fig 2) showed that detected 1 day 
IBD ELISA titers were shown to be nearly equal in Senawi (5449 \pm 371) and Lohmann $(4536 \pm 437)$ and titer of Baladi chicks was close to the for mentioned two breeds $(5327 \pm 371)$. The Dandrawi (4649 \pm 331$)$ and Fayoumi (4596 \pm 857$)$ were lower but close to each other. The SD values recorded in Fayoumi breed showed great variation in the recorded titers, while that of the other 4 groups seamed to be homogenous Comparing the 22 day decline manner in titer it was cler that the loss in titer in Fayoumi (3494) and Lohmann (3413) are nearly equal and followed by Dandrawi (3093) and Baladi (2972) those showing lower titers. Therecorded titer $\leq$ 400 was detected at 43 days in Lohmann, Baladi and Senawi, 37 days in Dandrawi and 31 in Fayoumi. Percentage of decline from its original values showed that Fayoumi last (75.95\%) at 22 days followed by $(66.53 \%)$ in Dandrawi followed by (62.78\%) Lohmann,(55.79) Baladi and (55.19) Senawi. Prediction equation was calculated for each breed that allows the forecast of antibody titer decay. High correlation was observed between dependant and independent parameters of the regression analysis (Table 2) and (Fig 3).Different breeds showed different slope values that indicate differences in the decay of maternal antibodies and the predication of antibody titer for each breed as the slope in decline curve in Lohmann chicks showed highest values followed by Dandrawi chicks while the Fayoumi and Baladi were as the same values and on the other hand the Senawi showed the lowest value. The loss in titer in Fayoumi (3494) and Lohmann (3413) are nearly equal and followed by Dandrawi (3093) and Baladi (2972) those showing lower titers. The recorded titer $\leq 400$ was detected at 43 days in Lohmann, Baladi and Senawi, 37 days in Dandrawi and 31 days in Fayoumi. Percentage of decline from its original values showed that Fayoumi last $(75.95 \%)$ at 22 days followed by $(66.53 \%)$ in Dandrawi followed by (62.78\%) Lohmann, (55.79) Baladi and (55.19) Senawi. The slope in decline curve in Lohmann chicks showedhighest values followed by Dandrawi chicks while the Fayoumi and Baladi were as the same values and on the other hand the Senawi showed the lowest value. Fayoumi, Baladi, Senawi and Dandrawi were nearly equal while the Lohmann was also the fastest in growth rates.

\section{References}

Amer, M. M.; Bastami, M. A.; and Khalifa, D. E. G. A. (1984): Studies on outbreaks of Infectious Bursal disease in chicken flocks. 1- Isolation and identification of causative strains. Beni-Suef Vet. Med. Res. 5: 158-171.

Amer, M. M.; Bastami, M. A.; Khalifa, D. E. and Hamouda, A. S. (1986): Serologic incidence of Gumboro disease virus infection in chicken flocks in Cairo district. Assiut vet. Med. J. 17 (33): 211-216.

Ayoub,N. N. K. and Malek,G. (1976):Identification of the pathogen Gumboro disease in Egypt. Monatshefte fur Vet.Med, 3(3):106-108.

Bastami, M. A. (1980): Studies on Gumboro disease in chickens and its relation to vaccination against some poultry diseases. Ph.D. thesis, poultry diseases, Cairo Univ. Benton, W. J.; Cover, M. S. and Rosenberger, J. K. (1967): Studies on the transmission of the Infectious bursal agent (IBA) of chickens. Avian Dis.11: 430-438.

Chettle,N.J.;and Wyeth ,P.J.(1994):Protection against challenge with very virulent infectious bursal disease virus using various vaccines and different regimens. Giessen,Germany,Instute Fur Geflugelkrahei 10:119-124.

Cheville, N. F. (1977): Studies on the pathogenesis of Gumboro disease in the bursa of Fabricius, spleen and thymus of the chicken. Am. J. Pathol.. 51:527-551.

Corley, M. M.; Giambrone, J. J..and Dormitorio, T. V . (2002): Evaluation of the immune response and detection of infectious bursal disease viruses by reverse transcriptasepolymerase chain reaction and enzyme-linked immunosorbent assay after in ovo vaccination of commercial broilers. Avian Dis. 46: 803-809.

Cosegrove,A. S. (1962): An apparently new disease of chicken - avian nephrosis Avian Dis 6: 385-389.

Eidson,C.S.(1980): Vaccination of breeder chickens and their progeny with a live or with an inactivated oil emulsion infectious bursal disease virus vaccine. Development in Biological Standardization .51:251-261.

El-Batrawi, A. M. and El-Kady, M. F. (1990): Studies on severe outbreaks of infectious bursal disease. 3Determination of the critical age of susceptibility in maternally immune chicks. $2^{\text {nd }}$ Scientific Conf. Egypt. Vet. Poult. 264-269.

El-Sergany, H. A.; Moursi, A.; Saber, M. S.; and Mohammmed, M. A. (1974): A preliminary investigation on the occurrence of Gumboro disease in Egypt. Egypt. J. Vet. Sci., 11:7.

Fahey, K.. J.; Crooks, J. K.. and Fraser, R.A.( 1987). Assessment by ELISA of passively acquired protection against infectious bursal disease virus in chickens. Aust. Vet. J. 64, 203-207.

Fahey,K.J.;Champan,A.J.;Macreadie,I.G.;Vaughan,P.R ;Mckern,N.M.;Skicho,J.I.;Ward,C.W.;and

Azad,A.A.(1991): A recombination sub unite vaccine that protect progeny chickens from infectious bursal disease.

Giambrone,J.J.andClay,R.P.(1986):Evaluation of immunogenicity ,stability ,pathogenicity and immunodepressive potential of 4 commercial live infectious bursal disease vaccine. Poult.Sci., 65:1287-1290.

Giambrone,J.J; and Closser, (1990):Efficacy of live vaccines against serologic serotypes of infectious bursal disease virus. Avian Dis. 45:144-148.

Goddard, R. D.; Wyeth, P. J. and Varney, W. C. (1994): Vaccination of commercial layer chicks against infectious bursal disease with maternally derived antibodies.Vet.Rec.,194:273-274.

Hassan, M. K., Afify, M. A., Aly, M. M., (2002): Studying the susceptibility of vaccinated and unvaccinated Egyptian chickens to very virulent infectious bursal disease virus. Avian Pathol.31:149-156. 
Kouwenhoven, B. and van den Bos, J., (1994): Control of very virulent infectious bursal disease Gumboro in the Netherlands with more virulent vaccines. In: Proceedings of International Symposium on infectious bursal diseases and chicken infectious anemia Rauischholzhausen, Germany, pp. 262-271.

Marquardt, W.; Johnson, R. B.; Odenwald, W. F. and Schlotthober, B. A. (1979): An indirect enzyme-linked immunosorbent assay (ELISA) for measuring antibodies in chickens infected with infectious bursal disease virus. Avian Dis.24:375-385.

Mazariegos, L. A. ; Lukert, P. D. and Brown, J. (1990): Pathogenicity and immunosuppressive properties of infectious bursal disease intermediate strains. Avian Dis., 34:302-208.

Mousa, S.; Bayoumi, A.; Shahata, M.; and Ibrahim, A. (1983): Infectious bursal disease in Fayoumi chickens. Assiut Univ. V. Med. J. 10(20): 181-185..

Solano,W.; Giambrone, J. J. ; Williams, J. C. ; Lauerman, L. H. ; Pangala, V. S. and Garces, C. (1986b): Effect of maternal antibodies on timing of initial vaccination of young white leghorn chickens against infectious bursal virus. Avian Dis., 30:684-652.

Steel, R. G. D. and Torrie, J. H. (1960): Principles and procedures of statistics. McGraw-Hill Book Comp. Inc. New York, Toronto, London, pp.99-131.
Van den Berg, T. P.; Lambrecht, B.; Morales, D.; Gonez, M.; and Meulemans, G. (1999): Partial protection of chickens against IBDV by DNA vaccination. Proceeding of the Keystone Symposium: DNA Vaccines: Immune responses, mechanisms and manipulating antigen processing. Snowbird, UT.12-17 April.

Van Den Berg, T. P. (2000): Acute Infectious bursal disease in poultry. Avian Path., 20:133 143.

Van Den Berg,T.P.; and Meulemans, G.(1991):Acute infectious bursal disease in poultry :protection afford by maternally derived antibodies and interference with live vaccination.Avian Pathol.,20(3):409-421.

Wyeth, P. J. and Chettle, N. J. (1990):Use of infectious bursal disease vaccine in chicks with maternally derived immunity.Vet.Rec., 126:577-578.

Wyeth, P. J.; Chettle, N. J. and Mohepate, A.R. (1992): Use of an inactivated infectious bursal disease oil emulsion vaccine in commercial layer chicks. Vet.Rec.,11:30-32.

Wyeth, P.J., Gough, R.E., Cullen, G.A., (1981a): Immune responses of breeding chickens to trivalent oil emulsion vaccines, responses to Newcastle disease and infectious bursal disease. Vet Rec.24:72-75.

Wyeth, P.J., O'Brien, J.D., Cullen, G.A., (1981b): Improved performance of progeny of broiler parent chickens vaccinated with infectious bursal disease oilemulsion vaccine. Avian Dis. 25:228-241.

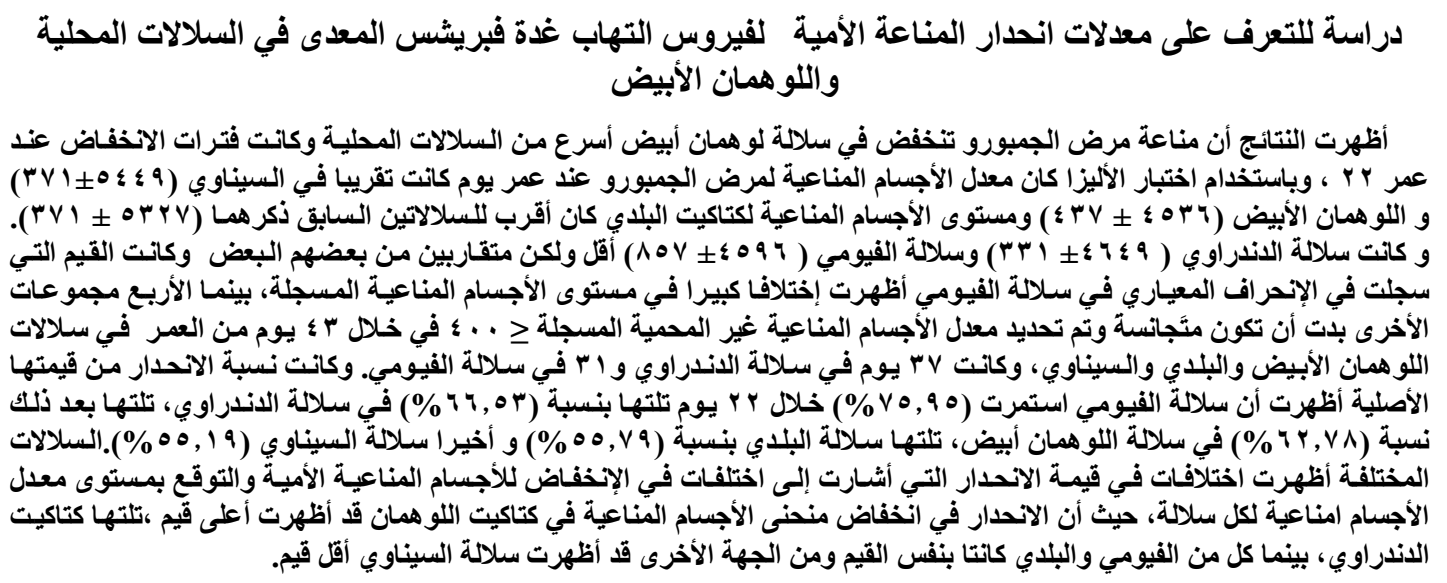


